\title{
Characteristic of Stress According to Student Clinical Training in Department of Radiology
}

\author{
Changmoo Baek*, Sooin Chae**, Jeongkoo Kim* \\ Dept. of Radiological Science, Hanseo University ${ }^{*}$, Dept. of Radiology, Hallym University Medical Center ${ }^{* *}$ \\ 방사선(학)과 학생 임상실습에 따른 스트레스 특성 \\ 백창무*, 채수인**, 김정구* \\ 한서대학교 방사선학과 ${ }^{*}$ 한림대학교 성심병원 영상의학과 ${ }^{* *}$
}

\begin{abstract}
Department of radiology implements the hospital-based clinical training to accept medical treatment techniques and to adapt experiences for students. However, it might cause negative effects to training education, leading to doubt about major and pressure about training as lots of students experience clinical treatment and complex stress in unfamiliar environment. Regarding this, pressure element that students can experience and diverse variables of training were compared and analyzed. With students in department of radiology for 6 colleges and universities, from September 15th to October 25th in 2011.

The degree of stress for students in training was shown high in the fields of cost(3.06) and trainers(3.02). Value and ideal(2.94), role and experiment(2.93), training environment(2.74) and relationships among trainees (2.64) were followed in the order. Except expense regarding stress from clinical training, but in all factors, women showed higher pressure level than $\operatorname{men}(\mathrm{P}<.05)$ and in stress range according to BEPSI-K, a meaningful difference was shown in fields of training environment, relationships among trainees and role and experiment $(\mathrm{P}<.01, \mathrm{P}<.001, \mathrm{P}<.05)$. Therefore, It has been confirmed that there is correlation between stress of students and satisfaction for clinical training with each other closely.
\end{abstract}

Key Words : Clinical Training, Stress, BEPSI-K

\section{요야}

방사선(학)과는 학생들의 실무적응과 진료기술의 수용을 도모하고자 병원 임상실습교육을 실시하고 있다. 그러나 임상실습현장에서 낮선 환경과 진료업무를 체험함으로써 많은 학생들이 복합적이고 다양한 스트레스를 경험하고 있 다. 때로는 실습의 부담감과 전공에 대한 회의로 이어져 실습교육에 부정적인 결과를 초래할 수도 있다. 이에 방사선 (학)과 학생들의 임상실습 시 경험할 수 있는 스트레스에 대해 그 요인들을 파악하고자 전국 3년제 4년제 대학 중 6 개 대학의 방사선(학)과 재학생을 대상으로 2011년 9월 15일에서 10월 25일까지 설문조사를 실시하였다.

방사선(학)과 학생들이 임상실습에서 경험하는 스트레스 정도는 비용적인 측면(3.06)과 임상지도자(3.02)에 관련 한 영역에서 높게 나타났으며, 이어서 가치와 이상(2.94), 역할과 실습활동(2.93), 실습환경(2.74), 실습생 간 관계 
(2.64)의 순으로 나타났다. 임상실습 스트레스 요인에 대해 비용적인 측면을 제외한 모든 요인에서 여성이 남성보다 스트레스 수준이 높게 나타났으며 $(\mathrm{P}<.05), \mathrm{BEPSI}-\mathrm{K}$ 구분에 따른 스트레스군 간에는 실습환경, 실습생 간 관계, 역 할과 실습활동 영역에서 유의한 차이를 나타냈다 $(\mathrm{P}<.01, \mathrm{P}<.001, \mathrm{P}<.05)$. 따라서 임상실습에 임하는 학생들의 스트 레스가 임상실습의 만족도와 상호 밀접한 상관관계를 가짐을 확인하였다.

중심단어: 임상실습, 스트레스, BEPSI-K

\section{I. 서론}

방사선(학)과에서는 학생들이 졸업 후 전문적인 방 사선사로서 원활한 실무 적응이 가능하도록 관련 보 건 지식과 진료 기술을 수용할 수 있는 능력을 함양하 고자 이론적 학습에 더하여 임상실습을 실시하고 있 다. 학교와 임상실습 기관은 임상실습 교육을 통하여 학생들이 학교에서 배운 전문적 지식과 기술을 실제 졸업 후 임상에서 즉시 적용할 수 있는 방법을 습득하 며, 방사선사로서의 올바른 자질을 갖추도록 한다 ${ }^{[1]}$. 이러한 임상실습 교육의 목표를 위하여 임상실습 현 장에서 학생들을 전문가로 육성하고 지도하는 명확한 교육목표와 임상실습 수행원칙이 각 임상실습 기관마 다 분명히 설정되어 있어야 한다. 또한 학생들은 환자 를 대상으로 한 방사선기술의 임상실무 경험을 쌓는 것에 머물지 않고, 병원 내 구성원 간 혹은 환자와의 관계를 통해 인격적인 대인관계의 소중함을 배우고 여러 상황에 따른 대처능력과 사회인으로서의 가치를 발견하고 발전시키는 기회와 계기가 될 수 있어야 한 다. 특히 급변하는 현대사회에서 발전일로에 있는 의 료기술과 환경에 따라, 임상실습 자체의 중요성과 더 불어 체계적이고 전인적인 교육이 이루어질 수 있는 시스템의 필요성은 더욱 커지고 있다 ${ }^{[2-3]}$.

일반적으로 방사선(학)과 임상실습 교육은 대학병원 과 중대형 종합병원 등 보건의료기관에서 이루지는 수 업으로 학교의 수업이 현장으로 옮겨진 수업의 형태라 할 수 있으며, 전공분야에 대한 학습이 충분히 이루어 진 이후 졸업 전 최종적으로 현장실습해 보는 기회를 가짐으로써, 그동안 학습된 이론의 확인과 보충의 기 간이 된다 ${ }^{[4]}$. 학생들의 임상실습을 위한 실습기관의 선 정은 교육기관이 위치하고 있는 지역사회의 진료기관 이 우선 대상이 되며, 위탁교육의 형식을 띠고 있다. 실습시기와 기간은 각 학교의 방사선(학)과마다 교과 과정과 프로그램 운영 형태에 따라 다양화 되어 있다.
임상실습을 하는 학생은 한정된 상황에서 제한된 지식만으로 새로운 환경에 적응해야 되는 피교육자 신분으로 인하여 복잡 다양한 의료현장과 제한된 업 무 역할 등으로 인하여 다양한 스트레스를 접하게 된 다. 임상실습 스트레스란 임상실습 과정에서 실습생이 경험하는 스트레스 원으로서의 상황을 말하며, 불안. 공포 등의 부정적 요인으로 인하여 효율적으로 임상 실습을 진행하는데 방해가 되는 상태를 말한다 ${ }^{[5]}$. 물 론, 일상생활에서 우리는 수많은 요인에 의해 스트레 스를 경험하게 되지만, 임상실습에 관한 스트레스에 한정하여 살펴보자면, 전문적인 기술의 숙달과 방사선 사로서의 자질 함양을 도모하는 임상실습 교육의 성 과는 비단 개인의 문제가 아니며 학교와 실습기관, 나 아가 의료산업 전반에 걸친 문제임을 자각할 때 학생 개개인이 경험하는 스트레스의 대처는 보다 근본적이 고 구체적으로 접근해야 할 문제라 여겨진다. 인문사 회학적 관점에서 스트레스와 관련된 연구는 스트레스 자체 혹은 직무나 직무 환경과 관련되어 발생하는 경 우에 대한 연구와 각 개인이 처해진 상황과 환경에 대 한 문제점을 갖고 대처가 필요한 경우에 대한 연구들 이 주류를 이루고 논의되어 왔다 ${ }^{[6]}$. 그러나 방사선(학) 과 학생들을 대상으로 한 임상실습과 스트레스에 관 한 연구는 활발하지 못한 실정이다.

따라서 본 연구에서는 만족스러운 임상실습이 교육 의 결과에 지대하고 중요한 영향을 끼친다는 사실에 따라 방사선과 학생들이 임상실습 교육에서 경험할 수 있는 다양한 종류의 스트레스 요인들을 파악하여 학생들의 일상적인 스트레스 수준과 임상실습에 관련 한 여러 요인에 따른 스트레스 정도와 문제점을 조사 하여 보았다.

\section{II. 연구대상 및 방법}

본 연구에서는 서울·경기, 강원, 충청, 호남, 영남 등 
전국 5 개 지역권의 방사선(학)과 3 년제, 4 년제 대학 중 6개 대학에서 실습을 마친 방사선(학)과 재학생을 대상 으로 설문조사를 실시하였다. 조사 기간과 자료 수집 은 2011년 9월 15일에서 10월 25일까지 총 40일간 이루 어졌으며, 회수된 총 322 부 중 연구에 사용하기 부적합 한 자료를 제외한 291 부를 본 연구에 사용하였다.

일반적으로 스트레스를 평가하는 방법으로는 생화 학적 측정법, 일상적인 면접과 상담을 통한 개인의 성 격, 행동 양식 측정법, 설문지를 이용한 정신·사회적 스트레스 측정법이 있다. 본 연구에서는 조사의 편의 성과 비용 절감을 이유로 설문지를 통한 자가 기입 방 법을 이용하였으며, 사전에 1 차로 구성한 설문지로 $\mathrm{H}$ 대학교 방사선학과 4학년 50 명을 대상으로 예비조사 를 한 다음, 그 결과를 바탕으로 재구성 된 설문지를 조사 도구로 이용하였다.

본 연구에 사용된 설문지 항목은 첫째, 연구대상자 의 일반적 특성 7 문항, 임상실습 관련 특성 7 문항, 임 상실습 관련 만족도 5 문항, 일상적인 스트레스 수준을 측정하기 위해서 '한국어판 BEPSI 설문서(BEPSI-K)스 트레스 측정도구를 이용하여 5문항을 구성하였다. BEPSI는 외래 환자의 생활변화에 따른 개인의 내적반 응 정도를 측정해 볼 수 있도록 개발된 도구로서 생활 의 변화에 따른 개인의 내적인 반응 정도를 측정한다. 본 연구에서는 대학생을 대상으로 스트레스 측정을 위해 사용한 설문지를 사용하였다 ${ }^{[7]}$. 둘째, 임상실습 스트레스 요인에 대한 항목은 실습환경, 실습대인관 계, 비용, 가치와 이상, 역할과 실습활동 관련 등의 영 역을 포함하는 27 문항으로 구성하였다. 임상실습 관련 조사도구는 임상실습 시 스트레스를 경험하는 상황에 대한 기존의 연구도구를 참고하여 재구성하였다 ${ }^{[8,9,10]}$. 각 문항별 스트레스 수준은 Likert scale 측정방법에 따라 5 점 평점 척도법을 사용하여 점수가 높을수록 스 트레스 정도가 높음을 나타낸다. 셋째, 스트레스 상황 에 대한 개인의 대처방식 항목은 Amirkhan의 스트레 스대처전략검사지'(Coping Strategy Indicator : CSI)를 기 초로 대학생을 대상으로 이 검사의 타당화 연구를 참 고하여 ${ }^{[9]}$ 본 연구의 목적에 맞도록 문제해결(problem solving), 회피(avoidance), 사회적 지지 추구(social support seeking)에 관한 10 문항으로 구성하였다. 이 영 역 역시 5점 평점 척도법을 사용하여 점수가 높을수록
해당되는 대처방식을 많이 취하는 것으로 분석하였다.

수집된 자료는 부호화하여 SPSS Ver. 18.0을 이용하 여 분석하였다. 본 연구에 사용된 스트레스 측정 문항 에 대해 베리멕스 회전방법으로 요인분석을 수행하였 으며, 주성분 분석으로 추출된 요인별로 내적일관성에 대한 측정 문항들의 신뢰도를 검증하기 위하여 Cronbach's Alpha를 구하였다. 임상실습 스트레스 측정 문항 전체의 신뢰도는 .902이었으며 BEPSI-K 신뢰도 는 .863으로 나왔다. 스트레스 요인에 따른 각각의 Cronbach's Alpha는 실습환경 관련 스트레스 .714, 임 상지도자 관련 스트레스 .803, 실습생간 관련 스트레스 .723 , 가치와 이상 관련 스트레스 .805 , 역할과 실습활 동 관련 스트레스 .830 으로서 설문 항목이 타당했음 을 나타냈다. 연구대상자 및 일반적인 실습관련 사항 은 빈도분석과 기술통계로 분석하였다.

\section{III. 결과}

\section{1. 연구대상자의 일반적 특성}

본 연구 대상자의 성별은 남성 $51.9 \%(151$ 명), 여성 $48.1 \%(140$ 명)이었으며 연령 분포는 25 세 이하가 $91.4 \%$ (266명)로 연구 대상자의 대다수를 차지했다. 학 년 분포는 3학년이 $82.8 \%$ (241명), 4학년이 $17.2 \%$ (50명) 로 연구대상자가 3 년제 방사선과 학생들이 더 많았다. 학교지역은 서울·경기지역이 $18.6 \%(54$ 명), 강원 $6.5 \%$ (19명), 충청 $16.85 \%$ (49명), 호남 $24.4 \%$ (71명), 영남 $33.7 \%$ (98명)를 이루고 있었고 질병 유무와 관련하여 건강상태는 좋다고 답한 학생이 $78.0 \%$ (227명)로 다수 를 차지했다. 평소의 대인관계는 보통 이상이 $96.2 \%$ (280명)로, 대다수의 학생들이 현재 대인관계에 별다른 어려움은 없는 것으로 나타났다. 종교는 없음 으로 답한 학생이 $59.1 \%$ (172명)로서 절반이상을 차지 했으며 불교와 기독교가 각각 $16.8 \%(49$ 명)와 $15.8 \%(46$ 명)로 비슷하게 나타났다(Table 1). 
"Characteristic of Stress According to Student Clinical Training in Department of Radiology"

Table 1. General characteristics of research subjects

단위: 명(\%)

\begin{tabular}{|c|c|c|}
\hline & 구 분 & $\mathrm{N}$ \\
\hline 성별 & $\begin{array}{l}\text { 남 } \\
\text { 여 }\end{array}$ & $\begin{array}{l}151(51.9) \\
140(48.1)\end{array}$ \\
\hline 연령 & $\begin{array}{l}20 \sim 21 \\
22 \sim 23 \\
24 \sim 25 \\
26 \text { 이상 }\end{array}$ & $\begin{array}{c}107(36.8) \\
75(25.8) \\
84(28.9) \\
25(8.6)\end{array}$ \\
\hline 학년 & $\begin{array}{l}3 \\
4\end{array}$ & $\begin{array}{r}241(82.8) \\
50(17.2)\end{array}$ \\
\hline 학교지역 & $\begin{array}{c}\text { 서울·경기 } \\
\text { 강원 } \\
\text { 충청 } \\
\text { 호남 } \\
\text { 영남 }\end{array}$ & $\begin{array}{l}54(18.6) \\
19(6.5) \\
49(16.8) \\
71(24.4) \\
98(33.7)\end{array}$ \\
\hline $\begin{array}{c}\text { 건강상태 } \\
\text { (질병유무) }\end{array}$ & $\begin{array}{c}\text { 있다 } \\
\text { 자주 아프다 } \\
\text { 없다 }\end{array}$ & $\begin{array}{r}30(10.3) \\
34(11.7) \\
227(78.0)\end{array}$ \\
\hline 대인관계 & $\begin{array}{c}\text { 매우 좋음 } \\
\text { 좋음 } \\
\text { 보통 } \\
\text { 나쁨 } \\
\text { 매우 나쁨 }\end{array}$ & $\begin{array}{c}33(11.3) \\
102(35.1) \\
145(49.8) \\
11(3.8) \\
-\end{array}$ \\
\hline 종교 & $\begin{array}{c}\text { 없음 } \\
\text { 불교 } \\
\text { 천주교 } \\
\text { 기독교 } \\
\text { 기타 }\end{array}$ & $\begin{array}{c}172(59.1) \\
49(16.8) \\
14(4.8) \\
46(15.8) \\
10(3.4)\end{array}$ \\
\hline
\end{tabular}

\section{BEPSI-K에 따른 일상적 스트레스}

일상생활에서 경험하는 스트레스가 건강에 미치는 부정적인 영향을 평가하도록 구성된 측정도구로서 불안지수, 우울지수, 생활변화량, 총 스트레스 수준과 상관성이 보고된 바 있는 BEPSI-K를 이용하여 본 연 구의 대상자가 느끼는 스트레스 수준을 낮음 ( 1.60), 중간(1.61 2.80), 높음(2.81 )으로 구분하였다.조사대상 학생의 $30.2 \%$ 가 낮은 스트레스군에 포함되었으며 $50.5 \%$ 가 중간 스트레스, $19.2 \%$ 가 높은 스트레스를 받 는 것으로 나타났으며, 평균 $2.21 \pm 0.83$ 으로 평상 시의 스트레스 수준은 높지 않은 것으로 나타났다(Table 2).
Table 2. Stress level according to BEPSI-K 단위: 명(\%)

\begin{tabular}{ccc}
\hline 구 분 & $N$ & $M \pm S D$ \\
\hline \hline$~ 1.60$ & $88(30.2 \%)$ & $1.34 \pm 0.23$ \\
\hline $1.61 \sim 2.80$ & $171(50.5 \%)$ & $2.23 \pm 0.34$ \\
\hline $2.50 \sim 5.00$ & $56(19.2 \%)$ & $3.53 \pm 0.52$ \\
\hline \hline 합계 & $291(100 \%)$ & $2.21 \pm 0.83$ \\
\hline
\end{tabular}

\section{3. 임상실습 스트레스 요인 분석}

연구 대상자에 대한 BEPSI-K 스트레스 구분에 따라 임상실습 스트레스를 요인별로 비교해 보았다. 비용 측면과 임상지도자 관련 요인에서 스트레스 수준이 높게 나타났으며, 일상적 스트레스에 대한 고 스트레 스의 군과 저 스트레스군 간에는 실습생 간 관계 영역 에서 경험하는 스트레스가 유의한 차이를 보이는 것 으로 나타났다 $(\mathrm{P}<.001)$. 또한, 실습환경 영역에서도 유 의함을 보였고 $(\mathrm{P}<.01)$, 역할과 실습활동 영역에서도 유 의하게 나타났다 $(\mathrm{P}<.05)$ (Table 3).

Table 3. Comparison of factors according to BEPI-K

\begin{tabular}{|c|c|c|c|c|}
\hline & 구 분 & $\mathrm{M} \pm \mathrm{SD}$ & $\mathrm{M} \pm \mathrm{SD}$ & P-value \\
\hline 실습환경 & $\begin{array}{c}1 \sim 1.60 \\
1.61 \sim 2.80 \\
2.50 \sim 5.00\end{array}$ & $\begin{array}{l}2.48 \pm 0.85 \\
2.84 \pm 0.77 \\
2.88 \pm 0.80\end{array}$ & $\begin{array}{c}2.74 \\
\pm 0.81\end{array}$ & .001 \\
\hline 임상지도자 & $\begin{array}{c}1 \sim 1.60 \\
1.61 \sim 2.80 \\
2.50 \sim 5.00\end{array}$ & $\begin{array}{l}2.93 \pm 0.96 \\
3.03 \pm 0.89 \\
3.14 \pm 0.97\end{array}$ & $\begin{array}{c}3.02 \\
\pm 0.93\end{array}$ & .391 \\
\hline $\begin{array}{c}\text { 실습생 간 } \\
\text { 관계 }\end{array}$ & $\begin{array}{c}1 \sim 1.60 \\
1.61 \sim 2.80 \\
2.50 \sim 5.00\end{array}$ & $\begin{array}{l}2.38 \pm 0.74 \\
2.68 \pm 0.73 \\
2.94 \pm 0.92\end{array}$ & $\begin{array}{c}2.64 \\
\pm 0.79\end{array}$ & .000 \\
\hline 가치와 이상 & $\begin{array}{c}1 \sim 1.60 \\
1.61 \sim 2.80 \\
2.50 \sim 5.00\end{array}$ & $\begin{array}{l}2.81 \pm 0.76 \\
2.96 \pm 0.64 \\
3.09 \pm 0.79\end{array}$ & $\begin{array}{c}2.94 \\
\pm 0.71\end{array}$ & .060 \\
\hline $\begin{array}{c}\text { 역할과 } \\
\text { 실습활동 }\end{array}$ & $\begin{array}{c}1 \sim 1.60 \\
1.61 \sim 2.80 \\
2.50 \sim 5.00\end{array}$ & $\begin{array}{l}2.75 \pm 0.77 \\
2.95 \pm 0.75 \\
3.15 \pm 0.84\end{array}$ & $\begin{array}{c}2.93 \\
\pm 0.79\end{array}$ & .012 \\
\hline 비용 & $\begin{array}{c}1 \sim 1.60 \\
1.61 \sim 2.80 \\
2.50 \sim 5.00\end{array}$ & $\begin{array}{l}3.02 \pm 1.12 \\
3.04 \pm 1.12 \\
3.16 \pm 1.22\end{array}$ & $\begin{array}{c}3.06 \pm \\
1.14\end{array}$ & .752 \\
\hline
\end{tabular}


"Journal of the Korean Society of Radiology, Volume 6, Number 4"

\section{4.임상실습 스트레스의 요인별 비교분석}

먼저 성별에 따른 임상실습 스트레스 수준을 요인 별로 측정한 결과 임상지도자, 실습생 간 관계, 가치와 이상, 역할과 실습활동 영역에서 성별에 따라 매우 유 의한 차이가 있음이 나타났으며 $(\mathrm{P}<.001)$, 실습환경 영 역에서도 성별에 따라 스트레스 수준이 유의하게 나 타났다 $(\mathrm{P}<.05)$. 임상실습 스트레스 수준은 BEPSI-K 스 트레스 수준보다 남, 여 모두에게서 더 높은 값을 나 타났으며, 일상적인 스트레스 또한 성별에 따라 통계 적으로 유의한 차이가 나타났다( $\mathrm{P}<.001)$, (Table 4).

Table 4. Comparison of stress factors according to Gender

\begin{tabular}{|c|c|c|c|}
\hline & $\begin{array}{c}\text { 남(N=151) } \\
\mathrm{M} \pm \mathrm{SD}\end{array}$ & $\begin{array}{c}\text { 여 }(\mathrm{N}=140) \\
\mathrm{M} \pm \mathrm{SD}\end{array}$ & P-value \\
\hline 실습환경 & $2.62 \pm 0.76$ & $2.87 \pm 0.85$ & .010 \\
\hline 임상지도자 & $2.78 \pm 0.89$ & $3.27 \pm 0.91$ & .000 \\
\hline 실습생 간 관계 & $2.45 \pm 0.74$ & $2.84 \pm 0.80$ & .000 \\
\hline 가치와 이상 & $2.74 \pm 0.73$ & $3.15 \pm 0.63$ & .000 \\
\hline $\begin{array}{c}\text { 역할과 실습 } \\
\text { 활동 }\end{array}$ & $2.74 \pm 0.75$ & $3.14 \pm 0.78$ & .000 \\
\hline 비용 & $3.03 \pm 1.15$ & $3.09 \pm 1.13$ & .694 \\
\hline BEPSI & $2.05 \pm 0.78$ & $2.39 \pm 0.85$ & .000 \\
\hline
\end{tabular}

연구대상자의 학교지역에 따른 임상실습 스트레스 를 측정한 결과 임상지도자 관계, 가치와 이상, 역할과 실습활동 영역에서 서울·경기지역이 각각 $3.18,3.11$, 3.06 으로 스트레스 수준이 다른 지역에 비해 가장 높 게 조사되었으며, 특히 임상지도자 관계 스트레스와, 역할과 실습활동 영역의 스트레스 요인에서는 타 지 역과 유의한 차이를 나타냈다 $(\mathrm{P}<05, \mathrm{P}<.01)$. 한편, 비용 측면에서는 강원지역이 3.89 로 타지역과 유의하게 조 사되었으며 $(\mathrm{P}<.01)$, 실습생간 관계 요인에서는 전 지역
에 걸쳐 상대적으로 낮은 평균값이 나타났다(Table 5).

Table 5. Comparison of stress factors according to district

\begin{tabular}{|c|c|c|c|}
\hline & 구 분 & $\mathrm{M} \pm \mathrm{SD}$ & P-value \\
\hline 실습환경 & $\begin{array}{c}\text { 서울·경기 } \\
\text { 강원 } \\
\text { 충청 } \\
\text { 호남 } \\
\text { 영남 }\end{array}$ & $\begin{array}{l}2.91 \pm 0.84 \\
2.46 \pm 0.86 \\
2.56 \pm 0.78 \\
2.73 \pm 0.76 \\
2.79 \pm 0.83\end{array}$ & .114 \\
\hline 임상지도자 & $\begin{array}{c}\text { 서울·경기 } \\
\text { 강원 } \\
\text { 충청 } \\
\text { 호남 } \\
\text { 영남 }\end{array}$ & $\begin{array}{l}3.18 \pm 0.91 \\
3.14 \pm 0.87 \\
2.69 \pm 1.08 \\
2.94 \pm 0.88 \\
3.13 \pm 0.88\end{array}$ & .044 \\
\hline $\begin{array}{c}\text { 실습생 간 } \\
\text { 관계 }\end{array}$ & $\begin{array}{c}\text { 서울 · 경기 } \\
\text { 강원 } \\
\text { 충청 } \\
\text { 호남 } \\
\text { 영남 }\end{array}$ & $\begin{array}{l}2.66 \pm 0.66 \\
2.59 \pm 0.87 \\
2.62 \pm 0.97 \\
2.56 \pm 0.71 \\
2.69 \pm 0.82\end{array}$ & .872 \\
\hline $\begin{array}{c}\text { 가치와 } \\
\text { 이상 }\end{array}$ & $\begin{array}{c}\text { 서울·경기 } \\
\text { 강원 } \\
\text { 충청 } \\
\text { 호남 } \\
\text { 영남 }\end{array}$ & $\begin{array}{l}3.11 \pm 0.58 \\
3.05 \pm 0.71 \\
2.79 \pm 0.85 \\
2.98 \pm 0.73 \\
2.87 \pm 0.68\end{array}$ & .137 \\
\hline $\begin{array}{l}\text { 역할과 } \\
\text { 실습활동 }\end{array}$ & $\begin{array}{c}\text { 서울·경기 } \\
\text { 강원 } \\
\text { 충청 } \\
\text { 호남 } \\
\text { 영남 }\end{array}$ & $\begin{array}{l}3.06 \pm 0.79 \\
3.06 \pm 0.75 \\
2.53 \pm 0.85 \\
3.01 \pm 0.68 \\
2.97 \pm 0.78\end{array}$ & .003 \\
\hline 비용 & $\begin{array}{c}\text { 서울 · 경기 } \\
\text { 강원 } \\
\text { 충청 } \\
\text { 호남 } \\
\text { 영남 }\end{array}$ & $\begin{array}{l}3.00 \pm 1.10 \\
3.89 \pm 0.99 \\
2.78 \pm 1.39 \\
3.15 \pm 0.94 \\
3.00 \pm 1.12\end{array}$ & .006 \\
\hline
\end{tabular}

평상시의 대인관계에 따른 임상실습 스트레스 수준 을 요인별로 측정한 결과, 대부분의 스트레스 요인에 서 유의한 관련성을 보이지 않았으나 역할과 실습활 동 영역에서의 임상실습 스트레스는 통계적으로 유의 
한 차이를 나타냈다 $(\mathrm{P}<.01)($ Table 6).

Table 6. Comparison of stress factors according to personal human relations

\begin{tabular}{|c|c|c|c|}
\hline & 구 분 & $\mathrm{M} \pm \mathrm{SD}$ & P-value \\
\hline 실습환경 & $\begin{array}{c}\text { 매우 좋음 } \\
\text { 좋음 } \\
\text { 보통 } \\
\text { 나쁨 } \\
\text { 매우 나쁨 }\end{array}$ & $\begin{array}{c}2.48 \pm 0.94 \\
2.71 \pm 0.82 \\
2.79 \pm 0.77 \\
3.18 \pm 0.78 \\
-\end{array}$ & .060 \\
\hline 임상지도자 & $\begin{array}{c}\text { 매우 좋음 } \\
\text { 좋음 } \\
\text { 보통 } \\
\text { 나쁨 } \\
\text { 매우 나쁨 }\end{array}$ & $\begin{array}{c}3.22 \pm 0.93 \\
2.88 \pm 0.95 \\
3.07 \pm 0.93 \\
3.11 \pm 0.74 \\
-\end{array}$ & .214 \\
\hline $\begin{array}{c}\text { 실습생간 } \\
\text { 관계 }\end{array}$ & $\begin{array}{c}\text { 매우 좋음 } \\
\text { 좋음 } \\
\text { 보통 } \\
\text { 나쁨 } \\
\text { 매우 나쁨 }\end{array}$ & $\begin{array}{c}2.48 \pm 0.68 \\
2.56 \pm 0.86 \\
2.71 \pm 0.78 \\
2.77 \pm 0.60 \\
-\end{array}$ & .289 \\
\hline 가치와 이상 & $\begin{array}{c}\text { 매우 좋음 } \\
\text { 좋음 } \\
\text { 보통 } \\
\text { 나쁨 } \\
\text { 매우 나쁨 }\end{array}$ & $\begin{array}{c}2.93 \pm 0.76 \\
2.86 \pm 0.78 \\
2.99 \pm 0.68 \\
2.94 \pm 0.38 \\
-\end{array}$ & .600 \\
\hline $\begin{array}{c}\text { 역할과 } \\
\text { 실습활동 }\end{array}$ & $\begin{array}{c}\text { 매우 좋음 } \\
\text { 좋음 } \\
\text { 보통 } \\
\text { 나쁨 } \\
\text { 매우 나쁨 }\end{array}$ & $\begin{array}{c}2.66 \pm 0.76 \\
2.78 \pm 0.78 \\
3.07 \pm 0.76 \\
3.23 \pm 0.79 \\
-\end{array}$ & .003 \\
\hline 비용 & $\begin{array}{c}\text { 매우 좋음 } \\
\text { 좋음 } \\
\text { 보통 } \\
\text { 나쁨 } \\
\text { 매우 나쁨 }\end{array}$ & $\begin{array}{c}3.18 \pm 1.21 \\
2.92 \pm 1.02 \\
3.11 \pm 1.19 \\
3.27 \pm 1.27 \\
-\end{array}$ & .468 \\
\hline
\end{tabular}

실습기관에 따라 임상실습 스트레스를 요인별로 측 정한 결과, 실습 환경 관련 스트레스 영역에서 중대형 병원을 제외한 기타 실습기관의 스트레스 수준이 3.92 로 전체에서 가장 높게 나타나 실습기관 간에 유의한 차이를 보였으나(P<.05), 비용적인 측면에서는 오히려 2.33 으로 가장 낮은 스트레스 수준으로 조사되었다 (Table 7).

연구 대상자의 실습기간 중 주거형태에 따라서는 임상지도자 요인에서 통계적으로 유의했으며 $(\mathrm{P}<.05)$, 특히 비용 측면에서 기타 집단(4.29)이 자택(2.87)에 비
해 큰 차이를 보이는 등, 집단 간에 유의한 차이가 있 음이 나타났다(P<.001), (Table 8).

Table 7. Comparison of stress factors according to the education institution

\begin{tabular}{|c|c|c|c|}
\hline & 구 분 & $\mathrm{M} \pm \mathrm{SD}$ & P-value \\
\hline 실습환경 & $\begin{array}{c}\text { 자택 } \\
\text { 친척집 } \\
\text { 자취 } \\
\text { 기타 }\end{array}$ & $\begin{array}{l}2.75 \pm 0.83 \\
2.74 \pm 0.73 \\
2.70 \pm 0.77 \\
2.82 \pm 1.09\end{array}$ & .970 \\
\hline 임상지도자 & $\begin{array}{c}\text { 자택 } \\
\text { 친척집 } \\
\text { 자취 } \\
\text { 기타 }\end{array}$ & $\begin{array}{l}3.13 \pm 0.91 \\
2.96 \pm 1.09 \\
2.74 \pm 0.89 \\
2.82 \pm 1.10\end{array}$ & .023 \\
\hline $\begin{array}{l}\text { 실습생 간 } \\
\text { 관계 }\end{array}$ & $\begin{array}{c}\text { 자택 } \\
\text { 친척집 } \\
\text { 자취 } \\
\text { 기타 }\end{array}$ & $\begin{array}{l}2.63 \pm 0.73 \\
2.72 \pm 0.84 \\
2.63 \pm 0.92 \\
2.71 \pm 1.13\end{array}$ & .957 \\
\hline 가치와 이상 & $\begin{array}{c}\text { 자택 } \\
\text { 친척집 } \\
\text { 자취 } \\
\text { 기타 }\end{array}$ & $\begin{array}{l}2.99 \pm 0.70 \\
3.09 \pm 0.75 \\
2.77 \pm 0.70 \\
2.62 \pm 0.94\end{array}$ & .061 \\
\hline $\begin{array}{c}\text { 역할과 } \\
\text { 실습활동 }\end{array}$ & $\begin{array}{c}\text { 자택 } \\
\text { 친척집 } \\
\text { 자취 } \\
\text { 기타 }\end{array}$ & $\begin{array}{l}2.93 \pm 0.79 \\
2.88 \pm 0.63 \\
2.94 \pm 0.81 \\
2.93 \pm 0.95\end{array}$ & .993 \\
\hline 비용 & $\begin{array}{c}\text { 자택 } \\
\text { 친척집 } \\
\text { 자취 } \\
\text { 기타 }\end{array}$ & $\begin{array}{l}2.87 \pm 1.10 \\
3.63 \pm 0.83 \\
3.32 \pm 1.15 \\
4.29 \pm 1.11\end{array}$ & .000 \\
\hline
\end{tabular}

Table 8. Comparison of stress factors according to residence

\begin{tabular}{c|ccc}
\hline & 구 분 & $M \pm S D$ & P-value \\
& & & \\
& 대학병원 & $2.71 \pm 0.78$ & \\
실습환경 & 종합병원 & $2.82 \pm 0.88$ & .039 \\
& 중형병원 & $2.38 \pm 0.80$ & \\
& 기타 & $3.92 \pm 1.01$ & \\
& 대학병원 & $3.01 \pm 0.94$ & \\
임상지도자 & 종합병원 & $2.98 \pm 0.88$ & \\
& 중형병원 & $3.71 \pm 0.91$ & .334 \\
& 기타 & $3.00 \pm 0.87$ & \\
& 대학병원 & $2.69 \pm 0.81$ & \\
실습생 간 & 종합병원 & $2.50 \pm 0.71$ & \\
관계 & 중형병원 & $2.13 \pm 0.65$ & .126 \\
& 기타 & $2.50 \pm 0.66$ & \\
& & &
\end{tabular}




\begin{tabular}{c|ccc}
\multirow{4}{*}{ 가치와 이상 } & 대학병원 & $2.90 \pm 0.71$ & \\
& 종합병원 & $3.01 \pm 0.72$ & .298 \\
& 중형병원 & $3.39 \pm 0.63$ & \\
& 기타 & $3.11 \pm 0.25$ & \\
역할과 & 대학병원 & $2.94 \pm 0.80$ & \\
실습활동 & 종합병원 & $2.90 \pm 0.73$ & \\
& 중형병원 & $2.58 \pm 0.98$ & .458 \\
& 기타 & $3.44 \pm 0.25$ & \\
& 대학병원 & $3.03 \pm 1.11$ & \\
비용 & 종합병원 & $3.14 \pm 1.15$ & \\
& 중형병원 & $3.50 \pm 1.38$ & .462 \\
& 기타 & $2.33 \pm 2.31$ & \\
\hline
\end{tabular}

\section{III. 고찰}

급변하는 현대사회의 의료 환경과 발전일로에 있는 의료 기술로 인하여 보건의료 분야의 임상실습은 그 중요성을 더하고 있다. 그러나 피교육자로서의 실습생 은 임상실습 현장이라는 새로운 환경에서 환자와 의 료인 간에 의료 업무를 경험함으로써 복합적이고 다 양한 스트레스를 접하게 되므로, 방사선학과 학생들이 임상실습 교육과정에서 경험할 수 있는 스트레스와 임상실습 스트레스를 효과적으로 대처할 수 있는 방 안에 대하여 연구 하였다.

연구대상자의 BEPSI-K에 따른 스트레스군의 일상 적 스트레스 수준에 대해서는 실습환경과, 실습생 간 의 관계 스트레스 요인에서 스트레스군 간에 유의한 차이를 보였다 $(\mathrm{P}<.01, \mathrm{P}<.001)$. 이는 치위생학과 학생을 대상으로 한 김현자(9)의 연구에서 BEPSI-K 수준이 2.0 인데 비해 환경요인이 3.0 으로 가장 높게 조사된 결 과의 내용과 일치하였으며, 각 스트레스군에 따라 비 교한 황선희(10)의 연구에서 대인관계와 환경요인에서 모두 유의한 상관관계를 보인 결과와 일치하였 다. $(\mathrm{P}<.01)$. 또한 평소 대인관계의 스트레스가 높을수 록 역할과 실습활동의 스트레스가 커지는 것으로 나 타났으며 $(\mathrm{P}<.01)$, 대인관계에 대한 스트레스 정도에 따 라서 실습만족도가 낮아진다는 황선희(10), 신성규(12) 의 결과와 일치하는 유의한 관계가 나타났다 $(\mathrm{P}<.05)$. 이는 학교나 실습기관의 평소 원만한 대인관계에 대 한 학생지도에 참고할 부분이라고 사료된다.

성별에 따른 BEPSI-K 스트레스 수준은 남녀 각각 $2.05,2.39$ 로 유의한 차이가 있었으며 $(\mathrm{P}<.001)$, 임상실습
스트레스도 BEPSI-K 스트레스 수준과 비교하여 각 요 인 전반에 걸쳐 남녀 모두 더 높게 나타났다. 여학생 의 경우 임상지도자와의 관계(3.27), 가치와 이상(3.15), 역할과 실습활동(3.09), 실습생 간 관계(2.84) 영역 순으 로 나타났으며 $(\mathrm{P}<.001)$, 실습환경에서도 유의한 차이를 보였다 $(\mathrm{P}<.05)$. 간호학과 학생을 대상으로 한 박민아 $(8)$ 의 연구에서도 일치하는 결과가 나타났는데 남성 2.99 , 여성 3.24로 남녀 간에 유의한 차이를 나타냈다 $(\mathrm{P}<0.01)$. 실습 스트레스에 대해 남녀 간에 비용적인 측면을 제외한 모든 요인에서 유의한 차이를 보였으 므로 여학생을 대상으로 하여 임상실습 활동에 대한 스트레스를 줄여주기 위한 별도의 지도와 프로그램이 필요하다고 사료된다.

연구대상자의 실습 중 주거형태 등, 개인적인 실습 관련 특성에 따라서도 임상실습 스트레스에 지대한 영향을 끼치는 경우도 확인할 수 있었다. 학교지역과 실습지역이 상이한 경우 대학병원과 대형병원이 수도 권 지역에 밀집해 있기 때문에 주로 서울·경기 지역에 서 임상실습 교육을 받는 경우, 학교지역에 따라서는 특히 비용적인 측면에서 많은 스트레스를 경험하는 경우가 있었으며 $(\mathrm{P}<.001)$, 임상실습을 통해 야기될 수 있는 학생 개개인의 실습 외적인 문제들이 다수 발생 할 수 있다는 가정 하에, 단순히 양질의 임상실습 교 육을 위해 지불해야 할 기회비용이 발생 할 수 있다는 측면과, 동시에 지방 임상실습 교육기관의 역할 확대 라는 과제가 국가사회적인 발전 계획 하에서 해결되 어져 나가야 할 문제라고 사료된다.

일반적으로 임상실습에 임하는 대부분의 학생들이 임상실습교육의 필요성을 지각하고 있으면서도, 실상 많은 학생들이 적응에 어려움을 토로하고 있으며 임 상실습에 대한 만족도와 성취도의 측면에서는 부정적 인 측면을 보이고 있다. 즉, 환자나 임상지도자와의 의 사소통의 어려움 등 대인관계에서의 경험부족과 익숙 하지 않은 병원환경에 대한 생소함에서 오는 심적 부 담감, 비교육적인 실습환경과 처우, 혹은 이론과 실제 의 차이에서 오는 심리적 혼란과 더불어, 전문지식의 부족 및 역할의 한정성으로 인한 자신감 결여와 불안, 초조, 피로 등의 임상실습 스트레스를 경험하고 있으 며, 이는 신체 및 심리적 증상과도 관계가 있는 것을 확인할 수 있었다. 본 연구의 결과 방사선학과 학생들 
의 임상실습 스트레스를 줄이고 더 높은 임상실습의 성과를 이끌어내기 위해 학교에서부터의 현실적인 전 공 교육과 더불어 대인관계와 전공에 대한 부담감을 줄일 수 있는 더욱 교육적인 실습 환경을 조성하고, 학생들의 교육을 담당하는 방사선사의 구체적이고 세 부적인 실습지도가 이루어질 수 있도록 학교와 실습 기관의 더욱 체계적인 프로그램의 개발과 다양화에 대한 논의가 요구되어진다.

\section{III. 결론}

본 연구는 방사선(학)과 학생들이 병원 임상실습 시 경험하는 스트레스 요인을 파악하여, 효율적인 실습지 도와 만족스러운 임상실습을 통해 학생들이 전문적 지식과 소양을 갖춘 방사선사로서 발전해 나가는데 도움이 되고자 2011년 9월 15일에서 10월 25일까지 전 국 3년제 4년제 대학 중 6 개의 대학의 방사선(학)과 재 학생을 대상으로 BEPSI-K의 스트레스 수준을 조사하 고 스트레스를 요인별로 비교 하였다.

방사선학과 학생들이 임상실습에서 경험하는 스트 레스 정도는 비용측면(3.06)과 임상지도자(3.02)에 관련 한 스트레스가 가장 높게 나타났으며 가치와 이상 (2.94), 역할과 실습활동(2.93), 실습환경(2.74), 실습생 간 관계(2.64)의 순으로 나타났다. 방사선(학)과 학생들 의 임상실습 스트레스 요인에 대해 비용적인 측면을 제외한 모든 요인에서 남녀 간에 유의한 관계가 나타 났으며 $(\mathrm{P}<.05)$, 비용적인 측면에 대해서 학교지역, 실 습지역, 주거형태에 대해 유의하게 나타났다 $(\mathrm{P}<.05)$. BEPSI-K 구분에 따른 스트레스군 간에는 실습생 간 관계 $(\mathrm{P}<.001)$, 실습환경 $(\mathrm{P}<.01)$, 역할과 실습활동 $(\mathrm{P}<.05)$ 영역에서 유의한 차이를 나타냈다. BEPSI-K 스트레스 수준에 대한 임상실습 스트레스에서는 성별( $\mathrm{P}<.001)$ 외, 학교지역 및 실습지역, 대인관계, 실습교육 및 분위기 만족도 간에 유의한 결과를 나타냈다( $\mathrm{P}<.05)$.

임상실습에 임하는 학생들의 스트레스가 임상실습 전반의 만족도와 상호 밀접한 상관관계를 가짐으로 만족도와 임상실습의 성과물이 직결되는 것임을 재인 식하여 실습환경의 개선과 실습생 개개인의 상황과 성향을 감안하여 임상실습이 진행되어야 할 것으로 사료된다.

\section{참고문헌}

[1] 유광열, 김현수, "대학 방사선학과 학생들의 임상실습에 대한 만족도 현황과 발전 방향”, 방사선기술과학, Vol. 29, No.4, pp.303-310, 2006.

[2] 최종학, 김창균, 김원철 외 1 인, "방사선사 업무의 발전에 관한 조사 연구”, 방사선기술과학, Vol.2 9, No. 3, pp.197-210, 2006

[3] 김학성, "방사선과 학생의 임상실습 만족도에 관한 연구", 방사선기술과학, Vol. 27, No. 4, pp.75-83, 2004

[4] 이은숙, “치과위생학개론”, 고문사, p.53, 1998

[5] 김영남, “치위생과 학생이 임상실습 시 경험하는 스트레스 요인에 관한 연구”, 경복논총, Vol. 4, No. 2, pp.373-391, 2000.

[6] 주영애, "사회복지현장실습에서의 스트레스 대처방안에 관한 연구”, 상지대학교 사회복지정책대학원 석사학위논문, 2007

[7] 배종면, 안윤옥, 박병주, “대학생 흡연량과 스트레스와의 관련성”, 예방의학회, Vol. 27, pp.1-10, 1994

[8] 박민아, “간호대학생의 셀프리더십, 임상실습 스트레스 및 대처방식", 경북대학교 대학원 석사학위논문, 2009.

[9] 김현자, "치위생과 학생들의 임상실습으로 인한 스트레스와 관련요인”, 경북대학교 보건대학원 석사학위논문, 2008.

[10] 황선희, "치위생과 학생이 교외 임상 실습에서 경험한 스트레스 요인에 관한 연구”, 단국대학교 행정법무대학원 석사학위논문, 2004

[11] 신혜진, “스트레스 대처 전략 검사의 타당화 연구”, 서울대학교 대학원 석사학위논문, 2002.

[12] 신성규, 임인철, "방사선학과 학생의 임상실습 만족도와 관련 요인”, 한국콘텐츠학회, Vol.10, pp.276-284, 2010. 